\section{Karolina Walancik-Ryba,}

Doctor of Legal Sciences, Legal Counsel, lecturer at the Malopolska State University in Oświęcim, judge assistant at the Katowice-Wschód District Court in Katowice, Poland

ORCID ID: https://orcid.org/0000-0002-9988-0145

\title{
RESEARCH ON FOSTER FAMILY IN POLISH LEGAL SYSTEM
}

The article «Research on foster family in Polish legal system» covers the issue of the child's rights to raise in the family in a situation where its "right / interest》 is being threatened in the light of Polish legislation. This right is implemented in the Polish legal system, among the others through the institution of a foster family. The author analyzes functioning of this institution both on the basis of applicable legal provisions and in practice on the research carried out in court on the court files. It presents conclusions regarding the legislator's assumptions and their implementation in judicial practice.

Key words: family, foster family, child, foster care, parents.

\section{Валанцік-Риба К.}

Досліджсеня про прийомну сім'ю у правовій системі Польщі

Стаття, у світлі польського законодавства, висвітлює питання прав дитини на виховання в сім'ї у ситуачії, коли існує загроза ї̈ «праву / інтересу. Це право реалізується в польській правовій системі, серед інших, через інститут прийомної сім'ї. Автор аналізує функціонування иьвого правового інституту як на основі діючих законодавчих положень, так і на практиці, використовуючи дослідження, проведені в суді за судовими матеріалами. У роботі представлені висновки щзодо припущень законодавия та їх реалізації у судовій практиці.

Ключові слова: родина, прийомна сім'я, дитина, прийомна допомога, батьки.

Introduction. The first natural care and educational environment for human is the family. Therefore, there is no doubt that the task of providing the child with adequate care, safety, development and upbringing belongs primarily to parents.

The right of the child to parenting, called the right of the child to the family [1, p. 5], originates, among others from the Convention on the Rights of the Child [2], ratified by Poland on June 7, 1991.

Parents are primarily responsible for the child. In certain situations, for various reasons, dependent or independent of the parents, they do not perform this task or do it incorrectly. The consequence of this may be a state in which the child's continued stay in the family constitutes a threat to his «good»/ interest. In such cases, it is the state responsibility to guarantee the child care, which for various reasons is not provided by the parents.

Interference in the sphere of parental care (authority) is an exceptional situation, limited to preventing the unfavorable situation of a child staying in the family [3] and taking into account the good of the child. And the responsibility of the state is of a subsidiary nature, expressed mainly in legislative and administrative activities aimed at providing the child with such goods that parents cannot provide for them - best interests of the child [4].

Family foster care in Poland. As soon as the child is separated from the family, the task of providing foster care towards parental care arises. In accordance with the legal regulations in force in Poland, foster care is exercised in two forms: family and institutional. Family foster care can be exercised in two forms, i.e. in the form of a foster family or in the form of a family children's home [5]. The first of them can be held as a foster family: related, non-professional, professional - including fulfilling the function of family and professional emergency service, and among them: therapeutic (for children with health deficits) [6], rehabilitation (for socially maladjusted children and adolescents, in respect of which a court ruling was issued for minors and juvenile mothers with children) [7, p. 771].

On the other hand, institutional foster care can be exercised in educational and care facilities, regional care and therapeutic facilities and pre-adoption intervention centers [8].

Preferences for family forms of foster care arise both from the provisions of international law in force in Poland - the Convention on the Rights of the Child [9], as well as comply with EU standards: Resolution No. (77) 33 of the Committee of Ministers of the Council of Europe on placing children outside the family.

(c) Karolina Walancik-Ryba, 2019 
Цивільне право і цивільний процес. Сімейне право. Трудове право. Міжнародне приватне право. Господарське право. Господарсько-процесуальне право.

The legal grounds for placing a child in a foster family are concluded in the Family and Guardianship Code, while the organization and functioning of the foster family in Poland has been regulated in the Act of 9 June 2011 on supporting the family and the foster care system [10].

I have attempted to analyze legal acts in Poland regarding foster families and judicial practice in cases of placing a child in a foster family. Due to the changes introduced in the foster care system in force to date, as well as controversy and the growing wave of criticism in the public opinion of the decisions of family courts regarding the selection of foster care in which children are placed.

For this purpose, I have analyzed a total of one hundred and fifteen cases resolved by individual district courts of the Katowice District, in which in the years 2012-2014 a decision was made regarding the placement of a child in a foster family [11]. Based on the data obtained from the statistical reports of the District Court in Katowice in the years 2012-2014, six hundred and nine decisions were issued regarding the placement of a child in a foster family. The Katowice District is the largest court district in Poland and covers as many as 14 district courts.

It should be noted that the Katowice District, which is a subordinate unit of the Court of Appeal in Katowice, out of forty-five regional courts [12] in Poland, it covers the largest number of district courts [13]. In total, fourteen family faculties operate in these courts, which is the largest number of family faculties among the regional courts in Poland.

The area of jurisdiction of the District Court in Katowice has been developing dynamically for many years, both in social and economic terms. Coal mines, metallurgical plants, coking plants, iron works, power plants and combined heat and power plants as well as factories were located in this area. This development allowed residents to maintain a high standard of living. Started at the end of the 1990s and the ongoing liquidation of factories and jobs caused a significant increase in unemployment and the development of pathological phenomena such as alcoholism, violence and crime. Economic emigration is currently a common phenomenon in this area. In particular young people who are parents go abroad to work, which contributes to the disintegration of the family.

The consequence of this phenomenon is often the burden of care and upbringing of a child who remains in the country, from parents to grandparents or older siblings. This condition causes legal problems related to the exercise of parental authority «at a distance.» Therefore, grandparents or siblings are often potential candidates for the role of a foster family for a child.

Results and conclusions. Despite the entry into force of the Act on family support, the definition of such terms as family, foster family, foster care still has not been developed. Included in the Act on family support, the definition of foster care system does not de facto define what foster care is. The legislator defines this concept by indicating only the purpose of the foster care system, which is to provide temporary care and upbringing to the child in cases of inability of parental care and upbringing.

The research shows that the concept of foster care is not the same as both parental and current care. Foster care is also not a parental authority or care within the meaning of the Civil Code.

In an attempt to define this concept, I defined foster care as an institution regulated by law whose purpose is to temporarily provide childcare and upbringing, whenever parents cannot fulfill these obligations, regardless of parental responsibility, by being properly prepared for it and properly qualified individuals or institutions to ensure continuity and stability in the care and upbringing of the child, the consequence of which should, as a rule, be the return of the child to the family, and in the absence of such a possibility, adoption of the child.

The research shows that a child placed in a foster family still remains the child of their parents with all the legal consequences concerning, among others alimony, inheritance. The child's marital status does not change, he or she has the status of a household member. There is no parental relationship with the foster family, only a legal bond, sometimes an emotional one.

In most of the analyzed cases, the court, ruling on placing a child in a foster family, interfered with the parental responsibility of parents - usually by limiting it. It should be emphasized that the practice of courts consisting in not depriving parents of parental authority, but only in limiting it in situations where the attitude of the child's parents does not indicate that it will ever improve, as was the case in most of the cases analyzed by me, causes difficulties in properly exercising takes care of the child in relation to the scope of the division of rights and obligations between the foster family and the child's parents.

As results from the conducted research, the legislator focused particularly on the support of professional foster families, including specialist professional foster families, and secondly on the support of non-professional foster families. This concentration consists in preferring this type of foster family compared to related foster families, both financially (they are entitled, according to the Act on supporting families, higher benefits to cover the costs of maintaining a child than related foster families, they may receive funds for the maintenance of a 
dwelling, a professional foster family may also receive a benefit to cover the costs of carrying out the necessary renovation of a dwelling, a professional foster family is entitled to remuneration for performing their function) [14] as well as in terms of assistance provided to these families in fulfilling their function (training, support family assistance or assistance) while taking care of children and at household work).

The research also shows that the legislator's lack of precision when creating the definition of a related foster family and a non-professional* foster family contained in the Act on supporting family causes serious problems related to shaping the rights and obligations of a foster family, in a situation where a foster family is created e.g. by a child's brother with his wife.

In all the analyzed cases, foster families formed by the ascendant or the siblings of the child and his spouse received a benefit to cover the costs of maintaining the child in the amount provided for related foster families, and therefore lower than for non-professional foster families. At the same time, the family members of this family who were not related to the child were required to complete training for a non-professional foster family. In view of the above, in the light of the provisions so structured, it is more beneficial for the child, from the point of view of the foster family's benefits and entitlements, to place the child in a one-person foster family in the form of a parent's spouse or child's siblings than in a foster family formed by a sibling or an initial child and their spouse.

In practice, according to the conducted research, the child is most often placed in a related foster family, created by grandparents who take care of him, bring him up and care for him, often from birth. Siblings (two, three, four or even five children) are often placed in these families. In addition, even in situations where the child has a disability certificate, it requires constant medical care, or has created educational problems, in practice it goes to a related foster family, and not to a specialist foster family. Children are rarely placed in professional foster families. There are not enough professional foster families, and they often also perform the function of guardianship, therefore they reach these families in urgent situations for a short period of time. In practice, courts often choose between placing a child in a «non-ideal», but related to a child, emotionally related or unfamiliar foster family (most often created by people who are related or related to the child) and placing the child in a care and educational institution.

In the draft act on supporting the family, the legislator assumed strengthening preventive measures and improving methods of working with the family for, inter alia, return of the child to the family [15]. The research shows that the institution of the family assistant introduced by the legislator does not function properly, and cooperation with the child's family is ineffective or missing (only in one case there was information about the cooperation of the assistant with the family in the case files).

In addition, as the analysis shows, at the research stage, in none of the cases, the child placed in a foster family did not return to the parents and was not adopted either. Thus, in practice, foster care often does not last temporarily, but is permanent.

To sum up the considerations, it can be stated that the solutions regarding foster custody in foster care contained in applicable legal regulations do not fully achieve the objectives and tasks of foster care, and thus do not contribute effectively to reducing family disintegration and proper implementation of the child's right to raise in family.

The above condition is caused by:

- first of all, the lack of precision of the legislator, who, considering that the issues related to foster care in a foster family and the legal status of a child in a foster family is complicated and complex, should be more accurate when creating the Act on family support and consistent, treating the current legal system as a coherent whole;

- secondly, legal solutions adopted by the legislator in the Act on family support that discriminate related foster families in relation to professional and non-professional foster families both in financial terms, as well as in terms of the possibility for these families to use forms of substantive and physical assistance in the exercise of their function.

To conclude, it should be noted that in the vast majority of cases analyzed, the decision on placing a child in a foster family was a form of regulating the legal situation and legalizing the existing and previously shaped facts in the form of care and upbringing of children by grandparents, siblings, distant relatives, even if not in every the case was optimal due to the individual needs of the child, taking into account the emotional relationship that exists between the child and the foster family.

\footnotetext{
* Pursuant to art. 41 section 1 of the Act on supporting a family, a foster family is made up of spouses or an unmarried person who has a child placed in order to ensure foster care in accordance with art. 41 paragraph 2 of the Act on supporting a family, a related foster family is formed by the spouses or a person not married, who are the ascendants or the child's siblings. However, a professional foster family or a non-professional foster family is formed by the spouses or a person who is not married, who is not the child's ascendants or siblings.
} 
Цивільне право і цивільний процес. Сімейне право. Трудове право. Міжнародне приватне право. Господарське право. Господарсько-процесуальне право.

Therefore, the legislator should focus more on helping foster families, because, as indicated, in practice they most often take care of a foster child and provide the child with a stable care and education environment. It is necessary to create legal solutions that will provide the child with an optimal substitute care and education environment suitable for their needs. Enabling the implementation of the child's right to a family. The child's needs depend on the situation in which the child is and on his individual characteristics, not on the type of foster family in which he is placed.

\section{References}

1. Gudbrandsson, B. Children in care institutions: prevention of institutionalization and alternative forms of care in European countries. Government Agency for Child Protection, Iceland, p. 5 [in English].

2. Convention on the Rights of the Child adopted by the General Assembly of the United Nations on November 20, 1989. Journal of Laws, 1991, 120.526 [in Polish].

3. Art. 9 par. 1 of the Convention on the Rights of the Child adopted by the General Assembly of the United Nations on November 20, 1989. Journal of Laws, 1991, 120.526) [in Polish].

4. Art. 3 of the Convention on the Rights of the Child adopted by the General Assembly of the United Nations on November 20, 1989. Journal of Laws. 1991, 120.526) [in Polish].

5. Art. 39 of the Act of 9 June 2011 on supporting the family and foster care system. Dz.U., 2011, Nr. 149, poz. 887 [in Polish].

6. Act of 27 August 1997 on vocational and social rehabilitation and employment of disabled persons. Journal of Laws, 1997. No. 123 pos. 776, as amended [in Polish].

7. Art. 39 of the Act of 9 June 2011 on supporting the family and foster care system Dz.U. 2011, Nr. 149, poz. 887 [in Polish]; Andrzejewski, M. (2013). (in:) Andrzejewski M., Dolecki H., Haberko J., Lutkiewicz-Rucińska A., Olejniczak A., Sokołowski T., Sylwestrzak A., Zielonacki A., edited by Dolecki H., Sokołowski T. Family and Guardianship Code, Wolters Kluwer SA, Warsaw, p. 771 [in Polish].

8. Art. 93 of the Act of 9 June 2011 on supporting the family and foster care system Dz.U., 2011, Nr. 149, poz. 887 [in Polish].

9. Art. 20 par. 3 of the Convention on the Rights of the Child adopted by the General Assembly of the United Nations on November 20, 1989. Journal of Laws, 1991, 120.526 [in Polish].

10. Art. 1122 of the Act of 23 April 1964 Civil Code [in Polish]; Act of 25 July 2014 amending the act on supporting the family and the foster care system as well as some other acts. Journal of Laws of 2014 item 1188 [in Polish].

11. Data from the statistical reports MS-S16r and MS-S18 for the years 2012-2014 (letter from the President of the District Court in Katowice Prez. 008-111 / 15 of 8 April 2015 [in Polish].

12. Regulation of the Minister of Justice of October 25, 2012 regarding the establishment of seats and areas of jurisdiction of appeal courts, regional courts and district courts. Journal of Laws of 2012, item 1223 [in Polish].

13. List of common courts of the Ministry of Justice. Retrieved from https://bip.ms.gov.pl/pl/rejestry-i-ewidencje/ lista-sadow-pszechnych [in Polish].

14. Art. 80 of the Act of 9 June 2011 on supporting the family and foster care system. Dz.U. 2011, Nr. 149, poz. 887 [in Polish].

15. Justification for the draft act on family foster care. Seym Print No. 628, Seym of the Republic of Poland of the 6 th term [in Polish].

Стаття надійшла до редакції 29.11.2019. 